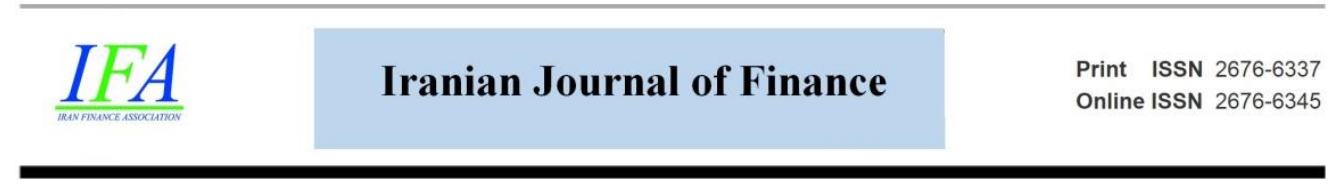

\title{
Information Content of Rating Banks Using Early Warnings Indicators
}

\section{Shoeib Abbasi}

Department of Accounting, Marivan Branch, Islamic Azad University, Marivan, Iran. (Email: abbasishoeib@gmail.com)

\section{Amin Nazemi*}

*Corresponding Author, Assistant Prof., Department of Accounting, School of Economics Management and Social Sciences, Shiraz University, Shiraz, Iran. (Email: aminnazemi@gmail.com)

\section{Navid Reza Namazi}

Assistant Prof., Department of Accounting, School of Economics Management and Social Sciences, Shiraz University, Shiraz, Iran. (Email: nnamazi@rose.shirazu.ac.ir)

Document Type: Original Article Received: 2021/03/18
Accepted: 2021/08/28
2021, Vol. 5, No. 4. 64-86.

Published: 2021/12/05

\begin{abstract}
It is necessary for decision-makers to have a rating system in the banking industry in order to reflect the banks' status and performance. Although most institutions across the countries have rating banks and financial institutions, there is a lack of a comprehensive rating system across Iranian banks. Rating requires identifying the appropriate criteria according to the environmental and macroeconomic conditions. For this purpose, 35 components are determined through the opinion of 34 banking and academic experts using the Delphi method and rating is done by the TOPSIS method for 15 banks listed on the Tehran stock exchange over the period of 5 years from 2015 to 2019. The results show that in addition to the quantitative aspects, the qualitative aspects and aspects related to environmental and macro aspects are effective in the native model of banks ratings. Also, there is a positive and significant relationship between banks stock prices variation and the suggested ratings.
\end{abstract}


The obtained results showed that there is a positive and significant correlation between the comprehensive model and early warning system so that the bank's position can be relatively described in the early warning system by identifying it within the model. This evidence addresses the need for a comprehensive consideration of proposed indicators to evaluate and rate banks.

Keywords: Bank, Rating, Quantitative Aspects, Qualitative Aspects, Market Reaction

DOI: https://doi.org/10.30699/IJF.2021.274065.1201

Publisher: Iran Finance Association

Copyright: author(s)

Type of License: Creative Commons License (CC-BY 4.0)

\section{Introduction}

The inability of people to analyze the banks status and the lack of a specific model to evaluate and compare them along with the lack of independent accreditation institutions have led the banking system to become disturbed in a way that they perform risky and out-of-scope activities. Having an applicable rating framework provides valuable information for people to make the right decision. The lack of an appropriate and publicly available rating system means ignoring the differences of banks, which might have many destructive outcomes. Therefore, today the evaluation of the national and international rating system is considered a necessity for banks. According to the dominant conditions of the country's economy and the numerous issues that financial institutions have caused for the country's economy, the importance of banks' ratings has significantly increased. On the other hand, attracting foreign investors into the country requires the necessary transparency and legal framework to provide banking safety. These reasons have necessitated the existence of an optimal accreditation system that would enable a comprehensive and rational evaluation of the country's conditions as well as meet the national and international requirements of banks. However, valid and official evidence on the ranking of banks in Iran has not been disclosed yet and only the periodic monitoring of the Central Bank has been sufficient, which also lacks ranking information and cannot meet the requirements of users. Therefore, the constant monitoring and providing appropriate approaches can reduce the occurrence of unpredictable economic fluctuations; despite the importance of this issue, a specific framework for periodic evaluation of the country's banks has not been determined yet in terms of financial performance accuracy, and bank evaluations are usually performed by the central bank inspectors' visiting of banks, which is not so effective due to the lack of comprehensive and local indicators (Abbasi \& Nazemi, 2020). In addition, to 
identify the major aspects and also the quantitative and qualitative components, this research proposes an appropriate framework for establishing a rating system in banks. Also, the correlation between stock price changes and the proposed rating model is studied to evaluate the efficiency and robustness of the proposed rating system and its justification.

For this purpose, the market reaction can be used to evaluate the results of the rating model. In fact, the result of accurate rating with an efficient model is accepted by users; Therefore, it is expected that a bank with good rating conditions will provide positive signals to users by giving useful information to users and determining the annual credit by rating agencies, as well as provide the necessary basis for suitable and reasonable reactions of users over the midterm and long-term periods. Therefore, one can expect that no sharp price changes in the annual period are observed in such banks. So, in the present study, the relationship between the rating given by the native model and the market reaction based on stock price changes is used to evaluate the proposed model.

The early warning system uses different criteria in countries to determine and monitor the credit risk at shorter intervals (Abdelsalam \& Abdel-Latif, 2020); as a result, due to the nature of the early warning system in determining the financial health status, this system can be used for the relative evaluation of the proposed local rating model; Although by now, a few reports have been published on the indicators of the early warning system in the Iranian banking system; however, the position of banks' ratings and the relationship between the early warning system and the rating model is not specified. Therefore, conducting this study is important and needs to be done.

The reminding of the paper is organized as follows: First, the conceptual framework and the literature are presented. Second, the methodology to construct a rating model is developed. Third, the modified comprehensive model is provided and robustness tests are also done using market reaction and early warnings system to the proposed rating framework. Finally, concluding remarks are provided.

\section{Research Background}

Rating is the assessment of the creditability of entities. Generally, factors that affect the entity rank is denominated in qualitative and quantitative. Identifying the effective factors is essential to determine the appropriate model for banks rating. Caporale, Matousek, Stewart (2012) and Hu, Haq, Pathan, Faff (2018) 
show that the structure of countries (in terms of legal, cultural, economic, ownership and management issues) influences the banks ranking.

Forecasting banks' performance is difficult because the features of the banking industry are unique. Because banks are one of the most important financial entities, they should be supported by their parents or public authorities. So, given the importance of external support, rating institutions consider two types of rating ratings named stand-alone and all-in rating. In stand-alone index, it is concentrated on the intrinsic characteristics of the entity. In All-in rating, there is extraordinary external support when the bank is in distress (Packer and Tarashev, 2011).

Given the variety of financial institutions as well as the banks rating criteria at the national and international level, it can be deduced that these institutions have appropriate and consistent criteria according to the institution's type and purpose and taking into account the cultural, political and economic conditions in the given country. For this reason, most countries use native indicators to evaluate their banks, depending on their needs and purposes. Despite the lack of a native rating system in Iran, numerous credit rating institutions have been established at the national and international levels. The three well-known and international rating institutions are Standard \& Poor's, Moody's and Fitch. Also, the institutions of Rating Agency Malaysia (RAM) and Pakistan Credit Rating Agency Limited (PACRA) can be mentioned at the country level. In all these institutions at the national and international level, the quantitative and qualitative criteria that are similar in some cases are applied (Mashayekh and Shahrokhi, 2015).

The most three famous rating agencies throughout the world are Fitch, Moody's and Standard \& poor's. Table 1 provides the differences between their methodologies. The three major rating institutes use quantitative and qualitative assessments using various criteria. However, they assign different weights to these factors to reach a final rating score.

The Fitch institution publishes two types of ratings: individual and issuer default ratings. Fitch also publishes all-in ratings separately by considering external support from the government or the bank owners. It is assumed that if the banks are supported the all-in rating score the Fitch assigns is higher than the stand-alone rating (Packer and Tarashev, 2011).

Another major rating agency in the world is Moody's. As table 1 shows Moody's also uses two types of ratings based on assessments of capital ratios and support providers. The institution suggested a new framework named joint default analysis (JDA) after the financial crisis. The framework emphasizes 
more on the external support called issuer ratings. In fact, the support by parents, governments or groups is considered to adjust the stand-alone rating (Packer and Tarashev, 2011).

Another famous agency is standard \& poor's. the agency uses country risks such as industry and economic risks called Banking Industry Country Risk Assessment (BICRA). After the basis is created, the agency adjusts the assessment with the BICRA score of the bank's home country and BICRA scores of all the countries it operates. It calls the process as anchor profiles. Standard \& poor's use bank-specific characteristics to map the anchor profile to bank stand-alone risk.

Generally, the methodology of these agencies is published, but the score determination they assign to banks is not publicly available. On the other hand, only the overall qualitative and quantities factors to determines rating are presented (Vestor et al. 2019).

There are some common quantitative and qualitative factors that are used in score rating. revenues, profitability and leverage are examples of quantitative factors. Corporate governance quality, political risk and financial policy are examples of qualitative factors.

Table 1. Rating Methodologies for Bank Fitch, Moody's and Standard and Poor's

\begin{tabular}{|c|c|c|c|}
\hline \multicolumn{4}{|c|}{ Rating methodologies for banks } \\
\hline & Fitch & Moody's & Standard \& Poor's \\
\hline $\begin{array}{l}\text { Stand-alone } \\
\text { assessments } \\
\text { (intrinsic } \\
\text { financial } \\
\text { strength) }\end{array}$ & $\begin{array}{l}\text { Focus on off-balance } \\
\text { sheet commitments, } \\
\text { funding and liquidity } \\
\text { risk }\end{array}$ & $\begin{array}{c}\text { Emphasis on } \\
\text { forward-looking } \\
\text { assessments of } \\
\text { capital ratios, based } \\
\text { on embedded } \\
\text { expected losses }\end{array}$ & $\begin{array}{c}\text { Focus on risk-adjusted } \\
\text { performance and ability } \\
\text { to grow capital from } \\
\text { profits }\end{array}$ \\
\hline $\begin{array}{l}\text { All-in ratings } \\
\text { (with external } \\
\text { support) }\end{array}$ & $\begin{array}{l}\text { Distinct ratings of } \\
\text { sovereign support } \\
\text { provide a floor }\end{array}$ & $\begin{array}{c}\text { Based on a joint } \\
\text { default analysis of } \\
\text { banks and providers } \\
\text { of support }\end{array}$ & $\begin{array}{c}\text { Anticipated support } \\
\text { increases with the bank's } \\
\text { systemic importance }\end{array}$ \\
\hline \multicolumn{4}{|l|}{$\begin{array}{c}\text { System-wide } \\
\text { assessment }\end{array}$} \\
\hline Country rating & $\begin{array}{l}\text { Based on: } \\
\text {-macro indicators } \\
\text {-average bank } \\
\text { rating }\end{array}$ & None & $\begin{array}{c}\text { Based on: } \\
\text {-macro indicators } \\
\text { - industry and regulatory } \\
\text { environment }\end{array}$ \\
\hline $\begin{array}{l}\text { Does systemic } \\
\text { risk affect }\end{array}$ & $\begin{array}{c}\text { Not explicitly; } \\
\text { anticipated support }\end{array}$ & $\begin{array}{c}\text { Not explicitly; } \\
\text { anticipated support }\end{array}$ & $\begin{array}{l}\text { Yes, through; macro } \\
\text { indicators for }\end{array}$ \\
\hline
\end{tabular}




\begin{tabular}{|c|c|c|c|}
$\begin{array}{c}\text { banks' } \\
\text { ratings? }\end{array}$ & $\begin{array}{c}\text { increases with the } \\
\text { bank's systemic } \\
\text { importance but falls } \\
\text { in times of } \\
\text { generalized distress }\end{array}$ & $\begin{array}{c}\text { increases with the } \\
\text { bank's systemic } \\
\text { importance }\end{array}$ & $\begin{array}{c}\text { countries where the bank } \\
\text { operates } \\
\text {-assessments of the industry } \\
\text { and regulatory environment in } \\
\text { the home country }\end{array}$ \\
\hline $\begin{array}{c}\text { Last major } \\
\text { changes }\end{array}$ & $\begin{array}{c}2005: \text { systemic risk } \\
\text { analysis }\end{array}$ & $\begin{array}{c}2007 \text { :joint default } \\
\text { analysis in support } \\
\text { assessment }\end{array}$ & $\begin{array}{c}2011 \text { :the overhaul of the } \\
\text { rating methodology. } \\
\text { Greater emphasis on: } \\
\text {-system-wide risks }\end{array}$ \\
-link from earnings to capital
\end{tabular}

( Packer \& Tarashev, 2011, P. 45)

Rating agencies have been criticized after the financial crisis because some investment banks such as Lehman Brothers had been collapsed and the rating agencies were accused of not adjusting the bank's rating properly. Scully and McLaughlin (2017) argue that the crisis is a product of the inefficient performance of rating agencies. Vester et al (2019) have also questioned the quality of accuracy and timeliness of prediction by rating agencies. Therefore, it seems that the banks should be evaluated using national rating frameworks based on economic and social factors. The present study tries to evaluate such a framework.

Considering the constructive factors of the proposed rating model, which includes quantitative and qualitative criteria of performance and dominant structure of banks, and on the other hand, considering the performance and components of the early warning system, it can be expected that the proposed model has a relative correlation with the early warning system; In this regard, the local model, given the extent of performance, which also includes the evaluation of the financial health of banks and having more components than the early warning system can have an appropriate prediction of the banks situation in terms of early warning system; Therefore, by comparing the results of the local model with the early warning system, it is possible to make a suitable evaluation of the proposed local model; Also, for further evaluation in this research, the correlation of the proposed model results with changes in stock prices is used that can be due to the market reaction to the situation of banks and as a result, a supplementary evaluation of the proposed local rating model is performed. 


\section{Literature Review}

Kurdbacheh and Farhadi (2021) have evaluated the effective factors on the financial inability of banks leading to bankruptcy. So, they have analyzed and evaluated the collected data by Logit model during 2006-2017. The obtained results show that the cost-to-income ratio has a positive and significant effect and the return on equity ratio has a negative and significant effect on financial inability.

Choi., Chit and Teo (2020) has evaluated the criteria used in Fitch, Moody's and S\&P rating agencies with 198 observations in the period of 20142016 through the regression correlation method. The findings have shown that the existence of micro and macro differences in the goals and sensitivities of rating agencies has led to differences in the result of rating and differences between institutions; For this reason, it is recommended to have commonalities for important goals; The results have also indicated that rating requires a broad view so that it is better to include indirect factors as well.

Atefifar and Fathi (2020) have studied the reaction of financial health indicators in the financial distress of banks. So, they have used CAMEL indicators for evaluation. Data from 9 banks have been used to perform the research; Logistic regression has also been used to analyze the data. The obtained results show that the ratios of asset quality, liquidity, capital adequacy and profitability have had the highest reaction in the financial distress, respectively.

Vester et al. (2019) examined the implementation of US-based credit rating by South African banks. They argue that the banks should adjust the external ratings to evaluate the borrowers. They provide some solutions to adjust external ratings to arrive at more suitable internal ratings.

Parsafard, Shirkund, Tehrani, and Mirlohi (2018) have studied the banks' independent credit ratings for depositors. They have determined 32 criteria with equal weights by the CAMELS rating system and Fuzzy Delphi method and have performed rating in 21 banks during 2012-2016. The results have shown that the Middle East Bank is at the first rank and Ayandeh Bank is at the last rank in terms of credit rating.

Rahman and Shohidul (2018) have evaluated the performance of Bangladesh's selected private banks using the CAMELS rating. The result of this analysis has represented the rates of Bangladeshi banks by the CAMELS system. 
Drago and Gallo (2017) consider the impact of sovereign rating revision on the activity of European banks in terms of regulatory capital, profitability, liquidity and lending supply. They argue that after the financial crisis Fitch rating refined the bank ratings, but the refinement did not change the overall ratings. Furthermore, they report positive rating surprises for large banks.

Erzae and Qasempour (2017) have performed ratings of Iranian private banks based on the CAMELS model. They use the Analytic Hierarchy Process(AHP) And determine the importance coefficient of each factor through the opinions of banking industry experts. The obtained results show that the banks of the Middle East, Pasargad, Qavamin and Karafarin have the most desirable performance based on the five-year data, respectively.

Beheshtinia and Omidi (2017) have concentrated on non-financial and social indicators to perform an evaluation of 4 sample banks. We think the implemented criteria in this study is not comprehensive to use in a rating system. Furthermore, the indicators have been weighted using operational managers in some branches of banks. It seems that more investigation is needed to identify and evaluate the factors. We try to provide a better index to rate the banks.

King, Ongena and Tarashev (2016) investigate bank stock prices reaction to credit rating changes that do not signal changes in default risk estimate. They argue that in July 2011, Fitch ratings refined their bank standalone ratings, which measure intrinsic financial strength. This refinement did not affect bank all-in ratings. They find more positive than negative rating surprises, in particular for large banks.

\section{Research Questions}

The questions to be addressed in this research are as follows:

1) What are the effective indicators in evaluating the banks rating in Iran?

2) How much influence do these indicators and their components have on the proposed model of banks ranking?

3) How is the rating of the selected banks using the proposed model?

4) How is the relationship between the proposed model's rating and stock prices variation?

5) Is there a correlation between the rate of the local model and the rating of the early warning system? 


\section{Research Conceptual Model}

This research provides a comprehensive and simplified rating framework according to the country's economic condition by comparing the models of reliable international rating institutions such as Fitch, S\&P and Moody's. Figure 1 represents this model.

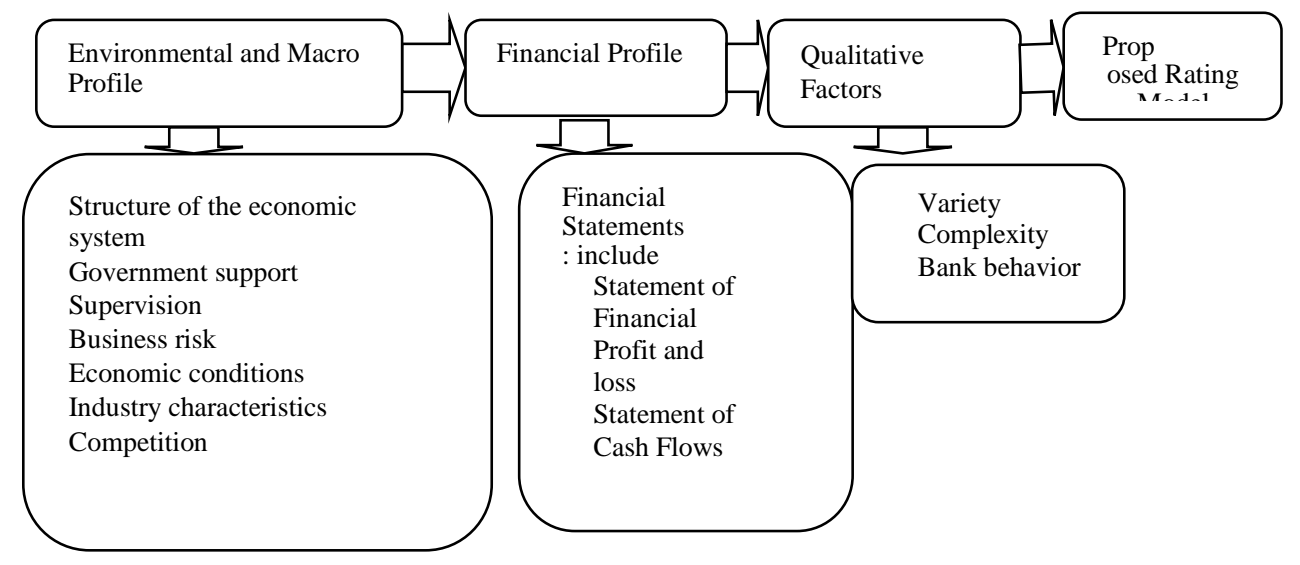

figure 1. The framework of the Rating Model

To conduct the research, first, the effective factors on the model are identified according to the theoretical foundations and the opinion of experts; then the final factors are extracted by the Delphi method by which the proposed rating of banks is presented by the TOPSIS method. Finally, to evaluate the efficiency and to justify the designed model, its relationship with market stock prices is studied. Figure 2 shows an overview of the research process.

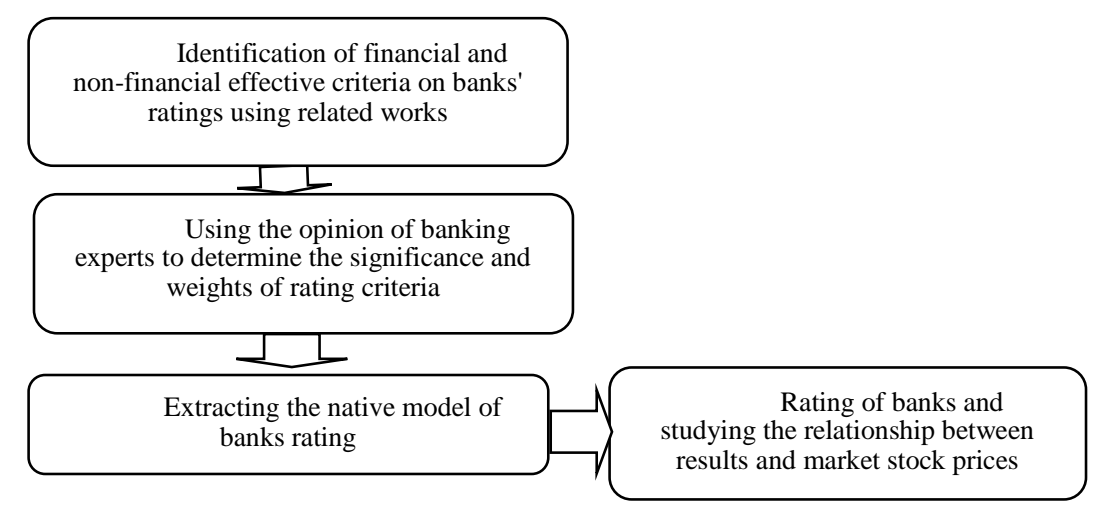

Figure 2. Overview of the research process 


\section{Research Methodology}

This research is empirical and it has a survey-based data collection method. In this research, two banking expert communities are used to collect survey data via a questionnaire. Also, the stock exchange and over the counter listed banks are used to obtain the data related to the components. To improve the quality and validity of this research, experts are selected with the following profile:

1. Having master or higher degrees in banking, accounting, finance, economics or management,

2. Having more than 10 years of management experience in the banking system or 5 years of banking industry analysis in investment, brokerage and financing companies, or

3. Be a well-known university professor with relevant work experience.

By examining the records, 34 eligible experts have been selected. It can be stated that the judgmental convenience sampling method has been used to select the samples. Judgmental sampling is a non-probability sampling technique in which the sample members are chosen only based on the researcher's knowledge and judgment. Judgmental sampling is most effective in situations where there are only a restricted number of people in a population who own qualities that a researcher expects from the target population. In order to test the rating criteria empirically, sampling was not used due to the limited statistical population of banks. For this, all the banks listed on the stock exchange and Over the Counter (OTC) with the following conditions in 2015 to 2019 have been selected:

- They have been listed in the exchange before 2015 .

- Their required information is available.

- Their financial statements have been audited.

- Their stock transactions are active daily.

In this case, the information of 15 banks has been collected.

\section{Data Collection Methods and Research Data Analysis}

This is a mixed quantitative/qualitative research because two types of information have been collected to answer the questions. A questionnaire is used to identify the indicators and relevant factors as well as to determine their influence on the ranking model. The Delphi method is used to specify the positions of given factors. The Delphi technique is a method that minimizes 
oppositions and inconsistencies by using the opinions of experts and groups on a particular issue, also it has more accurate results. The minimum number of experts is reported as 10 in the literature (Abbasi \& Nazemi, 2020). As the rating criteria are determined, the data of the selected factors are extracted from the audited financial statements at the Tehran Stock Exchange announcement website.

The geometric mean is used to determine the indicators' weights and the TOPSIS method is used for rating. The TOPSIS method (sorting of priorities upon similarity to the ideal solution) is one of the widely used methods. This method is based on the fact that each selected factor must have the minimum distance with the ideal positive factor (most significant) and the maximum distance with the ideal negative factor (least significant), which is considered as the main criterion of factors rating and prioritization (Kanani and Babazadeh, 2011, p26). For this purpose, the reason why we have chosen the TOPSIS method is its advantages over other rating methods used in researches of Froelich \& Hajek (2020) and Zhang, Zhan \& Wang, 2020; the advantages of the TOPSIS method according to the research of Liu, Wong, Li and $\mathrm{Hu}$ (2018) are mentioned in the following.

- Providing appropriate analyses in researches with a large number of criteria,

- Simplicity and accurate analysis in a short time,

- Quantification of qualitative criteria, as well as analysis and decision making with quantitative and qualitative criteria, are easy to perform in this method.

- The output of this method is a quantitative value that, in addition to determining the superior option, provides the ranking of other options numerically. This numerical value is the relative proximity that is the base of the TOPSIS method,

- Using the weight of criteria in analysis and considering them in decision making,

Determining the distance from the best and the worst option and that it is also based on mathematics.

In this regard, according to the mean, standard deviation and standardized functions, the homogeneous data are obtained; the steps of TOPSIS implementation are as follows. 
1. Initialization of the decision matrix. At this step, non-numeric indicators and verbal expressions must be converted to numeric values. Eq. (1) shows how to do it.

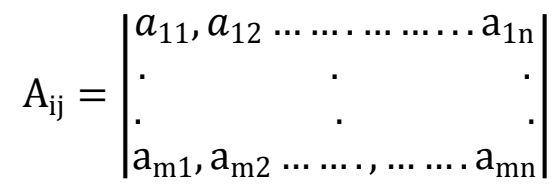

2. The decision matrix is converted into a normal decision matrix using. Relation 2). Therefore, for each column, the sum of the squares is calculated and each matrix element is divided by the square of the sum.

$$
\mathrm{n}_{\mathrm{ij}}=\frac{\mathrm{r}_{\mathrm{ij}}}{\sqrt{\sum_{\mathrm{i}=1}^{\mathrm{m}} \mathrm{r}_{\mathrm{ij}}^{2}}}
$$

3. Calculate a normal matrix or a balanced scale; to perform this step, a weight must be assigned to each of the criteria. This weight can be selected directly by the decision-maker so that each weight is between zero and one and the sum of the weights is equal to one. In this research, the average method is used to calculate weights. The given vector is converted to a diagonal matrix, that is, the nxn matrix in which the weights are on the original diameter and the other elements of the matrix are zero.

4. A balanced no-scale matrix is obtained using Equation 3:

$$
\mathrm{V}=\mathrm{N}_{\mathrm{D}} \cdot \mathrm{W}_{\mathrm{n} * \mathrm{n}}=\left|\begin{array}{c}
\mathrm{V}_{11}, \ldots \ldots . \mathrm{V}_{1 \mathrm{j}}, \ldots \ldots . \mathrm{V}_{1 \mathrm{n}} \\
\cdot \\
\cdot \\
\mathrm{V}_{\mathrm{m} 1}, \ldots \ldots . \mathrm{V}_{\mathrm{mj}}, \ldots \ldots . \mathrm{V}_{\mathrm{mn}}
\end{array}\right|
$$

5. Determining the assumed options of positive ideal and negative ideal; To form the positive ideal option (A+), the best value must be selected at each column of the V matrix; it means that if the corresponding index of that column has a negative aspect, the lowest value must be selected, and if it has a positive aspect, the highest value must be selected.

6. The distance of each option from the positive ideal option and the negative ideal option is calculated. So, V matrix information is used. The distance of option I to the positive ideal is denoted by $\mathrm{A}^{+}$and to the negative ideal by $\mathrm{A}^{-}$.

$$
\begin{aligned}
& A^{+}=\left\{\left(\max _{i} \quad V_{i j} \mid j \in J\right),\left(\min _{i} \quad V_{i j} \mid j \in J^{\prime}\right) \quad i=1,2, \ldots, m\right\}=\left\{V_{1}^{+}, V_{2}^{+}, \ldots, V_{j}^{+}, \ldots . . V_{n}^{+}\right\} \\
& A^{-}=\left\{\left(\min _{i} \quad V_{i j} \mid j \in J\right),\left(\max _{i} \quad V_{i j} \mid j \in J^{\prime}\right) \quad i=1,2, \ldots, m\right\}=\left\{V_{1}^{-}, V_{2}^{-}, \ldots, V_{j}^{-}, \ldots . . V_{n}^{-}\right\}
\end{aligned}
$$


7. Finally, Relation (6) is used to calculate the ratio of proximity to the ideal option.

$\mathrm{cl}_{\mathrm{i}+}=\frac{\mathrm{d}_{\mathrm{i}-}}{\left(\mathrm{d}_{\mathrm{i}+}+\mathrm{d}_{\mathrm{i}-}\right)} ; 0 \leq \mathrm{cl}_{\mathrm{i}+} \leq 1 ; \mathrm{i}=1,2, \ldots, \mathrm{m}$

Therefore, the obtained averages are multiplied by the actual values calculated for each variable, and then the rate of each bank is calculated in terms of the year by the TOPSIS method in Excel software. The interpretation of the results by the TOPSIS method is such that the variable with high $\mathrm{CL}^{+}$ has a higher rate, which means that the given variable has a shorter distance from the positive ideal option and a longer distance from the negative ideal option.

Finally, because, the data have collected has an abnormal distribution the Spearman correlation test is used to study the relationship between the suggested model rating framework and the stock price changes coefficient of variation.

\section{2 . Early Warning System's Model}

In this research, 13 leading variables in measuring the sustainability of banks according to Ahmadian (2015) are used to evaluate the early warning system to design a system for predicting the probable time of banks bankruptcy based on the type of ownership and to examine the effects of leading indicators. These variables are listed in Table 1.

Table 1. Leading variables in financial crisis prediction(Ahmadian,2015)

\begin{tabular}{|c|c|c|}
\hline Variable & Definition & Effect \\
\hline Annual change in equity & Change in bank capital compared to last year & + \\
\hline $\begin{array}{l}\text { The ratio of doubtful } \\
\text { receivables to all assets }\end{array}$ & The ratio of the cost of doubtful receivables to assets & - \\
\hline Cost to revenue & $\begin{array}{l}\text { Ratio of bank financial and non-financial expenses to } \\
\text { total revenues }\end{array}$ & - \\
\hline Deposits to branches & $\begin{array}{l}\text { The ratio of the total bank deposit to the number of } \\
\text { branches }\end{array}$ & + \\
\hline $\begin{array}{l}\text { Investments and } \\
\text { partnerships to total assets }\end{array}$ & The ratio of bank investments to total assets & - \\
\hline $\begin{array}{c}\text { Bank interest rate } \\
\text { liabilities to total assets }\end{array}$ & The ratio of total types of deposits to total assets & + \\
\hline Net profit to equity & The ratio of net profit to bank capital & + \\
\hline $\begin{array}{l}\text { Operating cost to total } \\
\text { assets }\end{array}$ & The ratio of bank operating costs to total assets & - \\
\hline $\begin{array}{l}\text { Liquid assets to income } \\
\text { assets }\end{array}$ & $\begin{array}{l}\text { The ratio of total cash assets in the bank, } \\
\text { participation bonds and receivables from the banking }\end{array}$ & + \\
\hline
\end{tabular}


Information Content of Rating Banks Using Early Warnings...

\begin{tabular}{|c|c|c|}
\hline & network to the bank assets & \\
\hline $\begin{array}{l}\text { Liquid assets to volatile } \\
\text { deposits }\end{array}$ & $\begin{array}{l}\text { The ratio of liquid assets to total deposit, savings and } \\
\text { transaction account deposit }\end{array}$ & + \\
\hline $\begin{array}{l}\text { The financial cost to total } \\
\text { assets }\end{array}$ & The ratio of bank financial cost to total assets & - \\
\hline $\begin{array}{l}\text { Investment deposit to total } \\
\text { assets }\end{array}$ & $\begin{array}{l}\text { The ratio of non-transaction bank deposits to total } \\
\text { assets }\end{array}$ & + \\
\hline Financial stability & $\begin{array}{l}\text { Logarithm ratio of total return on bank assets and } \\
\text { capital adequacy divided by the standard deviation of } \\
\text { the return on bank assets }\end{array}$ & + \\
\hline
\end{tabular}

\section{Research Findings}

\section{Proposed Rating Model}

At first, 52 factors have been identified by studying the theoretical foundations, then 35 factors have been determined according to viewpoints of the banking and academic experts on the importance of factors and availability of required data for this research; in addition, their significance, the way of measuring, as well as their influence on rating model have been recognized. Because the chosen factors are examined empirically, it is necessary to use data that can be collected normally. Table 2 shows the results of this process. As shown in this table, there are viewpoint-based possible factors that can be implemented to rate the banks. The sign and the weight of each factor are shown in the table. The aspects of rating are divided into three components; macro profiles, qualitative, and quantitative. The results show that based on the viewpoints it should be considered qualitative and macro profile aspects in addition to quantitative aspects.

Table 2. Suggested Comprehensive Rating Model

\begin{tabular}{|c|c|c|c|c|}
\hline Aspects & Factors & Measurement & $\begin{array}{c}\text { Probable } \\
\text { effect }\end{array}$ & Weight \\
\hline \multirow{10}{*}{ 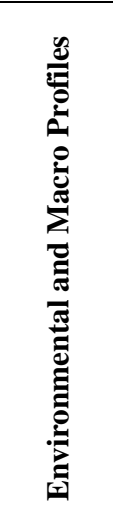 } & $\begin{array}{l}\text { Government } \\
\text { Support }\end{array}$ & Government ownership ratio & - & 0.017 \\
\hline & \multirow{5}{*}{$\begin{array}{c}\text { Macro-Economic } \\
\text { Variables }\end{array}$} & $\mathrm{GNP}=\mathrm{C}+\mathrm{I}+\mathrm{G}+(\mathrm{X}-\mathrm{I})+\mathrm{NFP}$ & + & 0.029 \\
\hline & & The bank share ratio of GDP & + & 0.03 \\
\hline & & Foreign exchange growth rate & - & 0.013 \\
\hline & & Interest rate & + & 0.029 \\
\hline & & Inflation rate & - & 0.03 \\
\hline & \multirow{4}{*}{$\begin{array}{c}\text { Banking industry } \\
\text { profile }\end{array}$} & Concentration Index & + & 0.063 \\
\hline & & Assets Market Share & + & 0.033 \\
\hline & & Market Share of Deposits & + & 0.033 \\
\hline & & Market Share of Revenues & + & 0.033 \\
\hline
\end{tabular}


Iranian Journal of Finance, 2021, Vol. 5, No. 4 (Abbasi, S.)

\begin{tabular}{|c|c|c|c|c|}
\hline \multirow{10}{*}{ 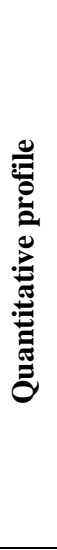 } & \multirow{2}{*}{ Capital adequacy } & Capital to assets ratio & + & 0.035 \\
\hline & & Debt to equity ratio & - & 0.013 \\
\hline & \multirow{2}{*}{ Asset quality } & Non-current loans to total loans ratio & - & 0.018 \\
\hline & & Total loans to total assets ratio & + & 0.035 \\
\hline & \multirow{2}{*}{ Profitability } & $\begin{array}{l}\text { The difference between the interest income and } \\
\text { the interest expense }\end{array}$ & + & 0.033 \\
\hline & & Net profit to total equity ratio & + & 0.032 \\
\hline & \multirow{3}{*}{ Liquidity } & Cash to total deposits ratio & + & 0.034 \\
\hline & & Cash to short-term liabilities & + & 0.035 \\
\hline & & Total loans to total deposits ratio & - & 0.033 \\
\hline & $\begin{array}{l}\text { Other sensitivity } \\
\text { of market risk }\end{array}$ & $\begin{array}{c}\text { The absolute value of foreign currency assets to } \\
\text { equity ratio }\end{array}$ & - & 0.029 \\
\hline \multirow{14}{*}{ 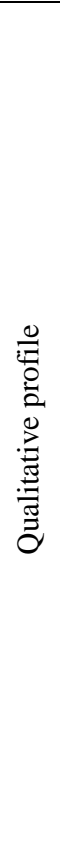 } & Diversification & $\begin{array}{l}\text { Revenue of diversified services to total revenue } \\
\text { ratio }\end{array}$ & + & 0.032 \\
\hline & \multirow{5}{*}{ Complexity } & Number of branches & + & 0.032 \\
\hline & & Institutional ownership ratio & - & 0.033 \\
\hline & & Non-institutional Ownership ratio & + & 0.011 \\
\hline & & $\begin{array}{l}\text { Total shares of real or legal } \\
\text { persons with more than } 5 \% \text { shares }\end{array}$ & - & 0.031 \\
\hline & & $\begin{array}{l}\text { Compliance of the Bank's Financial Statements } \\
\text { with International Financial Reporting Standards }\end{array}$ & + & 0.031 \\
\hline & \multirow{4}{*}{$\begin{array}{l}\text { Corporate } \\
\text { Governance }\end{array}$} & audit quality & + & 0.005 \\
\hline & & Transparency and information disclosure & + & 0.033 \\
\hline & & Independence of the Board & + & 0.032 \\
\hline & & Management Ownership & + & 0.032 \\
\hline & \multirow{2}{*}{$\begin{array}{l}\text { Dividend and } \\
\text { Bonus Policy }\end{array}$} & Dividend interest per share & + & 0.032 \\
\hline & & Bonus paid & + & 0.031 \\
\hline & \multirow{2}{*}{$\begin{array}{l}\text { Information } \\
\text { Quality }\end{array}$} & Over-investment & - & 0.029 \\
\hline & & Reporting delay & - & 0.029 \\
\hline
\end{tabular}

\section{Banks rating by suggested rating model}

In this section, banks are ranked individually for each year by the TOPSIS method. The five-year mean is also used to create more explanatory power and to have a longer-term view and a more rational prediction of banks' conditions. The obtained results are listed in Table 3. To prevent bias to sample banks the abbreviated name is chosen in the results. In this table, CL refers to the distance of the rate from the ideal and $\mathrm{R}$ denotes rating orders. 
Information Content of Rating Banks Using Early Warnings...

Table 3. Banks rating by native model

\begin{tabular}{|c|c|c|c|c|c|c|c|c|c|c|c|c|}
\hline \multirow{2}{*}{ Abbreviated Name } & \multicolumn{2}{|c|}{$\mathbf{2 0 1 5}$} & \multicolumn{2}{|c|}{$\mathbf{2 0 1 6}$} & \multicolumn{2}{|c|}{$\mathbf{2 0 1 7}$} & \multicolumn{2}{c|}{$\mathbf{2 0 1 8}$} & \multicolumn{2}{c|}{$\mathbf{2 0 1 9}$} & \multicolumn{2}{c|}{ 5-year period } \\
\cline { 2 - 7 } & $\mathbf{C L}$ & $\mathbf{R}$ & $\mathbf{C L}$ & $\mathbf{R}$ & $\mathbf{C L}$ & $\mathbf{R}$ & $\mathbf{C L}$ & $\mathbf{R}$ & $\mathbf{C L}$ & $\mathbf{R}$ & $\mathbf{C L}$ & $\mathbf{R}$ \\
\hline EN & 0.41 & 11 & 0.49 & 7 & 0.47 & 4 & 0.44 & 6 & 0.47 & 9 & 0.46 & 6 \\
\hline AN & 0.43 & 7 & 0.47 & 11 & 0.46 & 6 & 0.41 & 12 & 0.52 & 2 & 0.42 & 5 \\
\hline PA & 0.43 & 6 & 0.52 & 2 & 0.47 & 5 & 0.42 & 10 & 0.49 & 7 & 0.46 & 3 \\
\hline PS & 0.50 & 1 & 0.60 & 1 & 0.52 & 1 & 0.45 & 5 & 0.50 & 5 & 0.51 & 1 \\
\hline TJ & 0.33 & 15 & 0.48 & 8 & 0.47 & 3 & 0.45 & 3 & 0.49 & 6 & 0.44 & 11 \\
\hline ME & 0.42 & 9 & 0.47 & 9 & 0.44 & 11 & 0.43 & 8 & 0.50 & 4 & 0.45 & 8 \\
\hline SN & 0.42 & 8 & 0.52 & 3 & 0.45 & 8 & 0.45 & 2 & 0.47 & 10 & 0.46 & 4 \\
\hline SD & 0.42 & 10 & 0.43 & 14 & 0.46 & 7 & 0.44 & 7 & 0.49 & 8 & 0.45 & 10 \\
\hline ML & 0.48 & 2 & 0.50 & 6 & 0.44 & 10 & 0.39 & 14 & 0.43 & 14 & 0.45 & 9 \\
\hline KR & 0.45 & 5 & 0.50 & 5 & 0.47 & 2 & 0.42 & 9 & 0.53 & 1 & 0.47 & 2 \\
\hline PB & 0.38 & 14 & 0.42 & 15 & 0.36 & 15 & 0.4 & 13 & 0.45 & 12 & 0.40 & 15 \\
\hline AY & 0.48 & 3 & 0.50 & 4 & 0.40 & 13 & 0.38 & 15 & 0.44 & 13 & 0.44 & 12 \\
\hline HI & 0.40 & 12 & 0.44 & 13 & 0.45 & 9 & 0.46 & 1 & 0.52 & 3 & 0.45 & 7 \\
\hline Dy & 0.40 & 13 & 0.47 & 10 & 0.43 & 12 & 0.45 & 4 & 0.41 & 15 & 0.42 & 13 \\
\hline SM & 0.45 & 4 & 0.45 & 12 & 0.39 & 14 & 0.41 & 11 & 0.45 & 11 & 0.43 & 14 \\
\hline
\end{tabular}

The ratings show that the banks of the PS, KR and PA have the highest similarity to the positive ideal with the coefficients $0.51,0.43$, and 0.46 respectively. Also, PB, SM, and DY banks have the lowest similarity to the negative ideal respectively with the coefficients $0.4,0.42$, and 0.43 in the 5 year mean. To evaluate the results the robustness tests are needed to investigate whether the present ranking is a proper representation of the real rating status of the sample banks. This can be evaluated using a market reaction to this rating framework.

\section{Robustness Tests to evaluate the information content of rating index}

If the proposed rating model works accurately, it is assumed that market reaction to the rating indexes is significant. As the rating depends on both qualitative and quantitative factors which are evaluated continuously, it seems that the variation of the daily stock prices changes is a good benchmark to evaluate the proposed rating method. As shown in Table 4, for this purpose, the Kolmogorov-Smirnov test is used to determine whether the data distribution has a normal distribution.

Table 4. Kolmogorov-Smirnov Normalization Test

\begin{tabular}{|c|c|c|c|c|}
\hline Variable & Mean & St d. deviation & Kolmogorov-Smirnov test & Sig \\
\hline $\begin{array}{c}\text { Suggested model } \\
\text { ranking measures }\end{array}$ & 0.49267 & 0.101049 & 0.189 & $0.000^{*}$ \\
\hline
\end{tabular}

* Significant level is 95 percent presumed. 
According to the obtained results, the test is significant at the presumed level and therefore we should use non-parametric tests such as Spearman correlation statistics to investigate the correlation between rate benchmark and stock market price variation. Table 5 shows the results.

Table 5. Correlation results between rating and stock prices change the coefficient of variation using the Spearman test

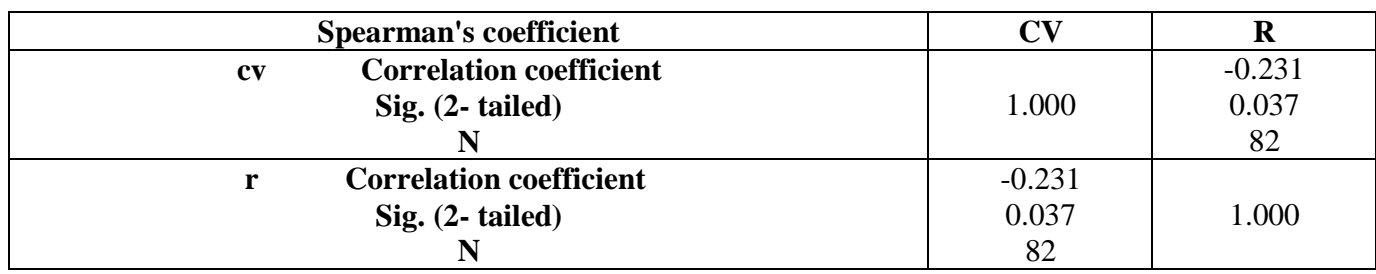

$\mathrm{CV}$ denotes the coefficient of variation of stock prices changes and $\mathrm{R}$ denotes the suggested rating index. The findings show that there is a negative relation between $\mathrm{CV}$ and $\mathrm{R}(-0.237)$. This means that the higher the rate (closer to one), the lower the price variation. On the other hand, market participants consider the quality of rating when they evaluate the banks throughout the year.

\section{Research Reliability}

The reliability of the variables refers to the variance and mean of the variables over time and the covariance of the variables across different years are constant. Therefore, using these variables in the model does not lead to false regression. For this purpose, the method of Levin, Lin \& Chu, Im, Pesaran \& Shin and Hardi are used for research variables reliability (Abdi et al, 2017).

Table 3. Reliability test of local variables

\begin{tabular}{|c|c|c|}
\hline Test & Value & Probability \\
\hline Levin, Lin \& Chu & $\mathbf{- 3 6 . 8 3 6 6}$ & $\mathbf{0 . 0 0 0}$ \\
\hline Im, Pesaran \& Shin & $\mathbf{3 9 . 6 4 8}$ & $\mathbf{0 . 0 0 0}$ \\
\hline Hardi & $\mathbf{5 . 8 6 8 9 6}$ & $\mathbf{0 . 0 0 0}$ \\
\hline
\end{tabular}

The probability is at a significant level of 0.000 , so it can be said that the reliability of the data is acceptable and the results of data analysis are reliable. 


\section{Banks Rating by Early Warning System}

According to the components of the early warning system, banks are rated using the TOPSIS method, shown in Table 4.

Table 4. Banks' rates based on early warning system criteria

\begin{tabular}{|l|l|l|l|l|l|l|l|l|l|l|l|l|l|l|}
\hline \multirow{2}{*}{ Bank } & $\mathbf{2 0 1 5}$ & $\mathbf{2 0 1 6}$ & \multicolumn{2}{l}{$\mathbf{2 0 1 7}$} & $\mathbf{2 0 1 8}$ & \multicolumn{2}{l|}{$\mathbf{2 0 1 9}$} & \multicolumn{2}{|l|}{ 5-year period } \\
\cline { 2 - 16 } & CL & R & CL & R & CL & R & CL & R & CL & R & Average & Rate \\
\hline EN & 0.609 & 9 & 0.53 & 9 & 0.575 & 5 & 0.538 & 2 & 0.487 & 9 & 0.546 & 3 \\
\hline AN & 0.610 & 8 & 0.532 & 8 & 0.569 & 7 & 0.458 & 11 & 0.51 & 4 & 0.533 & 6 \\
\hline PA & 0.617 & 6 & 0.625 & 1 & 0.68 & 2 & 0.37 & 15 & 0.536 & 3 & 0.554 & 2 \\
\hline PS & 0.652 & 4 & 0.507 & 11 & 0.452 & 13 & 0.494 & 6 & 0.481 & 10 & 0.513 & 11 \\
\hline TJ & 0.60 & 11 & 0.439 & 12 & 0.553 & 9 & 0.521 & 3 & 0.549 & 2 & 0.529 & 7 \\
\hline ME & 0.609 & 10 & 0.533 & 7 & 0.58 & 4 & 0.561 & 1 & 0.344 & 15 & 0.515 & 10 \\
\hline SN & 0.529 & 13 & 0.541 & 5 & 0.569 & 6 & 0.43 & 13 & 0.461 & 12 & 0.503 & 12 \\
\hline SD & 0.641 & 5 & 0.548 & 4 & 0.555 & 8 & 0.487 & 9 & 0.494 & 7 & 0.542 & 14 \\
\hline ML & 0.654 & 3 & 0.427 & 13 & 0.384 & 15 & 0.380 & 14 & 0.436 & 14 & 0.446 & 15 \\
\hline KR & 0.553 & 12 & 0.523 & 10 & 0.528 & 10 & 0.471 & 10 & 0.561 & 1 & 0.526 & 8 \\
\hline PB & 0.614 & 7 & 0.537 & 6 & 0.581 & 3 & 0.492 & 7 & 0.493 & 8 & 0.541 & 5 \\
\hline AY & 0.740 & 1 & 0.611 & 2 & 0.717 & 1 & 0.507 & 4 & 0.504 & 6 & 0.608 & 1 \\
\hline HI & 0.666 & 2 & 0.584 & 3 & 0.455 & 12 & 0.450 & 12 & 0.464 & 11 & 0.517 & 9 \\
\hline DY & 0.390 & 15 & 0.393 & 15 & 0.470 & 11 & 0.491 & 8 & 0.460 & 13 & 0.439 & 15 \\
\hline SM & 0.050 & 14 & 0.426 & 14 & 0.413 & 14 & 0.502 & 5 & 0.508 & 5 & 0.468 & 13 \\
\hline
\end{tabular}

Source: Research Findings

The obtained rating shows that AY, PS and EN banks have the closest proximity to the positive ideal and therefore have a higher rate over the 5-year period. And SM, ML and DY banks have the most distance from the positive ideal.

\section{Correlation and Predictive Power of Results}

In this research, the data panel method is used to fit the regression model. In order to measure the panel data against pooling data, the F-Limer test (determination of heterogeneity) is used; then, the relationship between the local rating model and early warning system is evaluated by the Hausman test (determining fixed or random effects), t-test, F-Fisher and determination coefficient. A simple linear regression model is used to measure the predictive power of early warning using the local model. 
Table 7. F-Limer test to determine panel or pooling method

\begin{tabular}{|c|c|c|}
\hline Test statistics & Degrees of freedom & Significance level \\
\hline 2.919 & 13.35 & 0.005 \\
\hline
\end{tabular}

The results of the F-Limer test indicate that the data panel method is suitable for the model evaluation; therefore, the Hausman test is used to determine the fixed or random effects, shown in Table 8.

Table 8. Hausman test to determine the fixed or random effects

\begin{tabular}{|c|c|c|}
\hline Test statistics & Degrees of freedom & Significance level \\
\hline 4.324 & 1 & 0.038 \\
\hline
\end{tabular}

The obtained results show that the fixed effects are suitable for the model evaluation $(0.0383<0.05)$; so, the regression model is fitted by the data panel method with random effects, given in Table 9.

Table 9. Results of regression model fitting and coefficient estimation

\begin{tabular}{|c|c|c|c|c|c|c|}
\hline Variables & $\begin{array}{c}\text { Coefficient } \\
\text { Symbol }\end{array}$ & Coefficients & $\begin{array}{c}\text { Standard } \\
\text { error }\end{array}$ & test t & $\begin{array}{c}\text { Significance } \\
\text { level }\end{array}$ & Result \\
\hline $\begin{array}{c}\text { Fixed } \\
\text { coefficient }\end{array}$ & $\beta_{0}$ & 0.231 & 0.164 & 1.408 & 0.167 & - \\
\hline $\begin{array}{c}\text { Local } \\
\text { rating } \\
\text { model }\end{array}$ & $\beta_{1}$ & 0.086 & 0.038 & 2.26 & 0.023 & $\begin{array}{c}\text { Direct and } \\
\text { significant }\end{array}$ \\
\hline $\begin{array}{c}\text { General } \\
\text { results of } \\
\text { the model }\end{array}$ & \multicolumn{2}{|c|}{\begin{tabular}{c} 
Coefficient of \\
\cline { 2 - 7 }
\end{tabular}} & \multicolumn{2}{|c|}{$\begin{array}{c}\text { Durbin-Watson } \\
\text { Test }\end{array}$} & F-Statistics & $\begin{array}{c}\text { Significance } \\
\text { level }\end{array}$ \\
\hline
\end{tabular}

The results show that Fisher's statistic is 2.729, which is higher than the corresponding statistic in Fisher's table; therefore, the fitted model is significant $(0.008<0.05)$. The coefficient of determination in the regression model indicates that $22.19 \%$ of the changes in the early warning criteria can be obtained based on the local model of banks rating. Also, the value of the Durbin-Watson statistic is 2.36, which indicates that there is no self-correlation among the error terms. The regression coefficient of the local model of banks rating is 0.086 and its significance level is $0.0236<0.05$. On the other hand, the given coefficient is positive, so with $0.95 \%$ confidence, the effect of the local model on the early warning criteria of banks is direct and significant; and as the bank's rate increases in the local model criteria, the bank's rate in the early warning criterion also increases. 


\section{Conclusion}

The results have shown that among the studied banks, PS and KR Banks have gained the first and second rates and $\mathrm{PB}$ has gained the last one, which has almost similar results with researches of Salimi, Ebrahimi Sarolia, Qasempour (2016) and Parsafard et al (2018). The findings indicate that in addition to financial aspects, it is necessary to consider the qualitative, environmental as well as macro aspects in evaluating banks. These findings have necessitated the usage of these aspects in rating as well-known rating institutions of Fitch, S\&P and Moody's. It can also be said that not taking into account the weight of factors' effect means ignoring the economic and political differences and dominant system of banks, which can lead to confusing results.

To test the efficiency of the designed native model in this research, the possible relationship between the obtained ratings and the market stock price has been studied where the findings indicated a positive and significant relationship among them. So, it can be concluded that a bank that has a better rating in the native model has a higher price than the others, which can indicate the bank's better performance. Therefore, it is expected that the rating results are logical and reliable and can be applied by decision-makers with various goals.

The ratings obtained from the local model with the early warning system are relatively close so that by determining the bank's rating in the local model, its position can be predicted relatively within the early warning system; therefore, it can be said that there is a proper correlation among them. These are logical and expected results. Given that in addition to the criteria of the early warning system, other criteria have been used in the indigenous model, it can be expected that the results of this model are more logical and real and can be used by decision-makers for various purposes. It seems that considering that in the local model, in addition to the criteria of the rapid warning system, other criteria have also been used, it can be expected that the results of this model are more logical and close to reality and can be used by decision-makers for various purposes.

To test the efficiency of the designed local model in this research, the possible relationship between the obtained ratings and market stock prices changes has been investigated where the findings have shown that there is a positive and significant relationship between them. So, it can be concluded that the bank that has a better rate in the local model has higher price changes in the market than the others, which can indicate its better performance. Therefore, it can be expected that the rating results are logical and reliable. 


\section{Suggestions}

The lack of reliable data about some factors has led to their exclusion, which could have led to better results in the rating model. The factors of banks' political conditions, Islamic banking, financial tools as well as laws observance are among the items that have been excluded due to the lack of data in this research. Therefore, it is recommended that reliable data are used along with other criteria in the evaluation of banks if any. It is also possible to analyze the weight of each factor's effect and its relevant aspects on the applied ranking models in different countries, as it can provide different results. Finally, it is recommended that this proposed process of banks ratings is employed in other industries, such as insurance and competing industries to meet the increasing requirements of customers.

\section{References}

Abbasi, S., \& Nazemi, A. (2020). Presenting and Evaluating the Banks Rating Model Using TOPSIS Technique. International Journal of Nonlinear Analysis and Applications, 11(Special Issue), 195-209.

Abdelsalam, M. A. M., \& Abdel-Latif, H. (2020). An Optimal Early Warning System for Currency Crises Under Model Uncertainty. Central Bank Review, 20(3), 99107.

Abdi, R; Zeinali, M \& Taghizadeh Khaneghah, V. (2017). The Effect of Managerial Ownership on the Relationship Between Free Cash Flows and Investment Inefficiency. Financial Accounting and Auditing Research, 9( 35), 157-191.

Ahmadian, A. (2015). Design of An Early Warning System to Predict When Banks Will be Exposed to Bankruptcy. Quarterly Journal of Applied Theories of Economics, 2(4), 119-144.

Atefi Far, A., \& Fathi, Z. (2020). Investigating the Effectiveness of Financial Health Indicators as Symbols of the Banking Financial Crisis by Using Multivariate Logit Models (Case Study of Listed Banks). Financial Engineering and Securities Management, 11 (42), 333-361. (In Persian)

Beheshtinia, MA., \& Omidi, P. (2017). Providing a New Approach to Rating Banks with New Global Standards. Strategic and Macro Policies. 5 (17), 53-27 .(In Persian)

Canaani, M., \& Babazadeh, Z. (2012). Development an Analysis Based on Ecological Capacity With TOPSIS Model (Case Study: Amol City of Mazandaran Province). Iranian Natural Ecosystems, 1 (4), 22-23 .(In Persian)

Caporale, G. M., Matousek, R., and Stewart, C. (2012). Ratings Assignments: Lessons from International Banks. Journal of International Money and Finance, 31(6), 
1593-1606.

Choy, S. Y., Chit, M. M., \& Teo, W. L. (2020). Sovereign Credit Ratings: Discovering Unorthodox Factors and Variables. Global Finance Journal, 100548.

Drago, D., \& Gallo, R. (2017). The Impact of Sovereign Rating Changes on the Activity of European Banks. Journal of Banking \& Finance, 85, 99-112.

Erza, A., \& Ghasempour, Sh. (2018). Ranking of Private Banks of Iran Based on Camels Model Using Combined Approach of Analytical Hierarchy Prosses. Financial Management Strategy. 5 (3), 118-99 .(In Persian)

Froelich, W., \& Hajek, P. (2020). IVIFCM-TOPSIS for Bank Credit Risk Assessment. In Intelligent Decision Technologies (pp. 99-108). Springer, Singapore.

Hu, D., Haq, M., Pathan, S., and Faff, R. W. (2018). New Evidence on National Culture and Bank Capital Structure. Pacific-Basin Finance Journal. 50, 44-46.

King, M. R., Ongena, S., and Tarashev, N. A. (2016). Bank Standalone Credit Ratings. BIS Working Paper No. 542. Bank for International Settlements.

Kurdbacheh, H., \& Farhadi, K. (2021) Investigating Financial Insolvency in The Iranian Banking System and its Determinants. Financial Engineering and Securities Management, 12 (46), 365-388. (In Persian)

Liu, H. C., Wang, L. E., Li, Z., \& Hu, Y. P. (2018). Improving risk evaluation in FMEA with cloud model and hierarchical TOPSIS method. IEEE Transactions on Fuzzy Systems, 27(1), 84-95.

Mashaykh, Sh., and Shahrokhi, S. S (2016). Corporate Credit Rating System in The World. Accounting Research, 4 (4), 131-148 .(In Persian)

Packer, Frank \& Tarashev, Nikola. (2011). Rating Methodologies for Banks. BIS Quarterly Review. June. 39-52.

Parsafard, M., Shirkvand, S., Tehrani, R., \& Mirlohi, S M. (2018). Independent Credit Ratings of National Banks. Journal of Industrial Management, 10 (4), 606-575 . (In Persian)

Rahman, Z., \& Shohidul, I. (2018). Use of CAMEL Rating Framework: A Comparative Performance Evaluation of Selected Bangladeshi Private Commercial Banks. International Journal of Economics and Finance, 10(1). (In Persian)

Salimi, M. J., Ebrahimi Sarveolya, M. H \& Qasempour, S. h. (2017). Designing A Domestic Model of Banking Ratings of Iranian Banks Based on Banking Health. Financial Research, 4 (18), 653-674 .(In Persian)

Scully, M. \& McLaughlin, D. (2017). Fin24: Moody’s slammed with massive $\$ 864 \mathrm{~m}$ penalty, viewed $\quad$ February $2017, \quad$ from http://www.fin24.com/Economy/moodysslammed-with-massive-864m-penalty- 
20170116

Verster, T., De Jongh, R., Greenberg, S., Fourie, E. \& De Wet, D., (2019).A Motivation for Banks in Emerging Economies to Adapt Agency Ratings When Assessing Corporate Credit. South African Journal of Economic and Management Sciences, 22(1), 1-11.

Zhang, K., Zhan, J., \& Wang, X. (2020). TOPSIS-WAA Method Based On a Covering-Based Fuzzy Rough Set: An Application to Rating Problem. Information Sciences, 539, 397-421.

\section{Bibliographic information of this paper for citing:}

Abbasi, Shoeib; Nazemi, Amin \& Namazi, Navid Reza (2021). Information Content of Rating Banks Using Early Warnings Indicators. Iranian Journal of Finance, 5(4), 64-86.

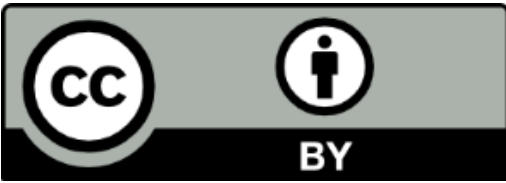

